\title{
Impact of Maize Formulated Herbicides Mesotrione and S-Metolachlor, Applied Alone and in Mixture, on Soil Microbial Communities.
}

\author{
Pierre Joly, ${ }^{1,2}$ Pascale Besse-Hoggan, ${ }^{3,4}$ Frédérique Bonnemoy, ${ }^{1,2}$ Isabelle Batisson, ${ }^{1,2}$ \\ Jacques Bohatier, ${ }^{1,2}$ and Clarisse Mallet ${ }^{1,2}$ \\ ${ }^{1}$ LMGE, Clermont Université, Université Blaise Pascal, 63000 Clermont-Ferrand, France \\ ${ }^{2}$ UMR 6023, CNRS, and Laboratoire Microorganismes: Génome et Environnement, Université Blaise Pascal, 63177 Aubière, France \\ ${ }^{3}$ SEESIB, Clermont Université, Université Blaise Pascal, 63000 Clermont-Ferrand, France \\ ${ }^{4}$ UMR 6504, CNRS, and Laboratoire de Synthèse et Etude de Systèmes à Intérêt Biologique, 63177 Aubière, France
}

Correspondence should be addressed to Pierre Joly, pierre.joly@univ-bpclermont.fr

Received 19 September 2011; Accepted 14 November 2011

Academic Editors: G. Berg and D. C. Moon

Copyright () 2012 Pierre Joly et al. This is an open access article distributed under the Creative Commons Attribution License, which permits unrestricted use, distribution, and reproduction in any medium, provided the original work is properly cited.

In order to reduce the amounts of pesticides used, and thereby their associated risks, new generations of less environmentally dangerous molecules with lower weight are currently being used in the mixtures sprayed on crops. Few studies have been made, however, to analyse their impact on the soil, and more particularly on the microorganisms living in the soil which maintain the essential functions of this ecosystem. By taking a microcosmic approach, we were able to assess the impact of the maize herbicides "cocktail" Mesotrione and S-metolachlor on global soil microbial activity, biomass, and structures, by using the formulated compounds, respectively, Callisto and Dual Gold (both registered brands of Syngenta). Our results highlighted a synergetic effect in "cocktail" microcosms resulting in an increase in the Mesotrione herbicide dissipation time and in an impact on the microbial community at onefold field rate equally to more than a single herbicide used at tenfold field rate.

\section{Introduction}

For several decades herbicides have been used in spray form to reduce unwanted vegetation in crops. However, the main indirect casualty of these pesticides, following their spraying, is the soil, and, more particularly, the microorganisms it contains which are essential to maintain the functions of the soil ecosystem $[1,2]$. So nowadays, European laws are converging to reduce the amounts of pesticides (Directive Cadre sur l'Eau 2000/60/ CE, http://www.eur-lex.europa.eu/LexUriServ/LexUriServ .do?uri=CELEX:32000L0060:fr:html. Directive Cadre sur les pesticides 91/414/CEE, http://www.eur-lex.europa.eu/ LexUriServ/LexUriServ.do?uri=CELEX:31991L0414:fr:html. Plan Ecophyto 2018, http://www.agriculture.gouv.fr/ ECOPHYTO-2018/) used, and, in doing so, reduce their associated risks. The lack of controls in pesticides targets has caused the revaluation of many first-generation molecules and their replacement with new generations of molecules with lower weight, which, therefore, are less dangerous to the environment [3]. To ensure the efficiency of these new pesticides, the trend is to multiply the molecules used for the same crop in combinations called "cocktails." Unfortunately, comparing to data on single pesticides (e.g., [1]), there are few studies concerned with the impact of these "cocktails" on the environment, particularly regarding their indirect impact on soil microbial communities. Some studies $[4,5]$, however, showed that when two herbicides were used simultaneously, their persistence in the soil was generally prolonged, and the environmental contamination potential increased. Among others $[5,6]$, Tejada showed an increased toxic effect of "cocktails" on biological microbial activity. In order to better understand the impact of pesticides, it is essential that the potential synergetic effects of combined herbicide mixtures on soil microbial communities are investigated further.

In this context, to replace the herbicide Atrazine, which was banned in 2003 [7], the triketone herbicide Mesotrione 
(2-[4-(methylsulfonyl)-2-nitrobenzoyl]-1,3-cyclohexanedione) is often used in combination with the chloroacetanilide herbicide S-metolachlor (2-chloro- $N$-(2-ethyl-6-methylphenyl)-N-[(1S)-2-methoxy-1-methylethyl] acetamide) on maize crops.

Mesotrione is a chemical derivative of a natural phytotoxin produced by Callistemon citrinus [3] which inhibits a critical enzyme, p-hydroxy-phenylpyruvate dioxygenase (HPPD), in carotenoid biosynthesis [8]. It was recently shown that it could have some impact on soil microbial communities when used alone [9] and that some of these metabolites could be more toxic than the parent molecule [10].

S-metolachlor is classified as an inhibitor of very long chain fatty acid (VLCFA) formation (HRAC (2007), http:// www.hracglobal.com/). It interferes with normal cell development and inhibits both cell division and cell enlargement [8]. The choice of S-metolachlor among the other herbicides sprayed together with Mesotrione, was made mainly because of its known difficult biodegradation [8] and because of its targets, which differ from those of Mesotrione.

Although we may know the impact of such pesticides when they are applied alone [1], it is necessary to study the "cocktails" used on fields to evaluate the real impact of pesticides on soil microbial communities. No studies were found in the literature which made reference to the effects of the combined application of Mesotrione + S-metolachlor on soil microorganisms. The objective of this paper, therefore, was to study the effect of the combination of these two molecules on soil microbial communities and ecological processes through the use of two herbicides commonly used for maize crops, being the formulated compounds Callisto and Dual Gold.

We assessed the impacts of the herbicide "cocktail" on global soil microbial activity, biomass, and structures. We also focused on the effect of the "cocktail" on potentially sensitive communities, such as phototrophic microorganisms and those involved in the nitrogen cycle. Our work was carried out using these herbicides at onefold field-rate, being the normal conditions of spraying, and at a tenfold fieldrate, to replicate the higher pressure of pollution encountered sometimes in the first millimetres of soil after spraying. To conduct this study we privileged a microcosm approach as a reliable substitute for field research into the effects of pesticides on soil ecosystems [11].

\section{Materials and Methods}

2.1. Experimental Design. Topsoil $(0-5 \mathrm{~cm})$ was collected in January 2010 from a fallow chernozem soil (determined using standard protocols of Arras Soil Analysis Laboratory, INRA, France; and according to FAO classification) located in the Limagne plain near Clermont-Ferrand (France). The soil was then sieved (mesh size $2 \mathrm{~mm}$ ) and preincubated under experimental conditions for two weeks, in large polyvinyl chloride (PVC) tanks.

The effects of Mesotrione and S-metolachlor herbicides on soil microbial communities when applied alone or in a "cocktail," were studied using two different doses: onefold field rate: $1 \times$ FR and tenfold field rate: $10 \times$ FR of formulated Mesotrione $\left(0,45 \mathrm{mg} \cdot \mathrm{kg}^{-1}\right.$ soil dry weight $(\mathrm{dw})_{\text {of active ingredi- }}$ ent (a.i.) for $1 \times \mathrm{FR}$ and $4,5 \mathrm{mg} \cdot \mathrm{kg}^{-1}$ soil $_{\mathrm{dw}}$ (a.i.) for $10 \times \mathrm{FR}$ of Callisto, $100 \mathrm{~g} \cdot \mathrm{L}^{-1}$ Mesotrione, Syngenta Crop Protection) and formulated S-metolachlor $\left(5,4 \mathrm{mg} \cdot \mathrm{kg}^{-1}\right.$ soil $_{\mathrm{dw}}$ (a.i.) for $1 \times \mathrm{FR}$ and $54 \mathrm{mg} \cdot \mathrm{kg}^{-1} \operatorname{soil}_{\mathrm{dw}}$ (a.i.) for $10 \times \mathrm{FR}$ of Dual Gold, $915 \mathrm{~g} \cdot \mathrm{L}^{-1} \mathrm{~S}$-metolachlor, Syngenta Crop Protection). The formulated herbicides were diluted in distilled water, and soil $\mathrm{pH}$ was measured after herbicide application to ensure a nonoccurrence of $\mathrm{pH}$ effects.

Each treatment $(\mathrm{C} 1$ and $\mathrm{C} 10$ for Callisto applied at $1 \times \mathrm{FR}$ and $10 \times$ FR, respectively; DG1 and DG10 for Dual Gold applied at $1 \times \mathrm{FR}$ and $10 \times \mathrm{FR}$, resp., $\mathrm{M} 1(\mathrm{C} 1+\mathrm{DG} 1)$ and M10 (C10 + DG10) for the Callisto/Dual Gold Mix applied at $1 \times \mathrm{FR}$ and $10 \times \mathrm{FR}$, resp.) was carried out on different soil subsamples in separate PVC tanks, by spraying and then mixing in the herbicides with a small rake. The control soil (T) was sprayed with distilled water only. Each soil subsample was divided into 20 microcosms (190 g of soil in PVC cylinders, height $=8 \mathrm{~cm}$, diameter $=10 \mathrm{~cm}$ ), leading to a total of 140 microcosms. Soil water content was adjusted to $35 \%$ of maximum water holding capacity (WHC), making it comparable to field moisture, and was monitored throughout the experiment by weighing the soil of each microcosm every week. The microcosms were covered with porous plastic film allowing air exchange while limiting soil dehydration and incubated in an experiment room with a day/night cycle (14:10) at $20^{\circ} \mathrm{C} \pm 2{ }^{\circ} \mathrm{C}$ for 93 days. Five randomly chosen microcosms from each treatment set were sacrificed on days 2, 8, 42, and 93. For each microcosm, microbial biomass, microbial respiration, $\mathrm{N}-\mathrm{NO}_{3}{ }^{-}$and $\mathrm{N}-\mathrm{NH}_{4}{ }^{+}$(except at day 93), and photosynthetic pigments were obtained from fresh soil aliquots. The remaining soils were stored at $-20^{\circ} \mathrm{C}$ for DNA analysis, herbicide quantification, enzymatic activity analysis, and carbohydrate and protein measurements.

2.2. Herbicide Dissipation. At the beginning of the experiment, soil samples were checked for the absence of Mesotrione, S-metolachlor, and other pesticides (multiresidues117 scan, LDA 26 Laboratory). In order to check the amount of herbicide initially spread on the soil and track its dissipation, Mesotrione and S-metolachlor concentrations were monitored for each treatment for three out of five replicate microcosms on every sacrificing day. Mesotrione was extracted and concentrations were quantified, as described by Crouzet et al. [9]. S-metolachlor was extracted by adding $10 \mathrm{~mL}$ of $\mathrm{MeOH} / \mathrm{H}_{2} \mathrm{O}(4 / 1)$ onto $5 \mathrm{~g}$ of fresh soil, and stirring for $24 \mathrm{~h}$ using an orbital shaker at $50 \mathrm{rpm}$ and at room temperature. Herbicide concentration of soil liquid extracts was quantified by high-performance liquid chromatography (HPLC) on an Agilent Series 1100 chromatograph (Courtaboeuf, France) equipped with a reverse-phase column (C18 Zorbax Eclipse column, $150 \mathrm{~mm} \times 4.6 \mathrm{~mm}, 5 \mu \mathrm{m})$ at $22 \circ \mathrm{C}$ and a diode array detector set at $\lambda=254 \mathrm{~nm}$ for Mesotrione and $\lambda=$ $220 \mathrm{~nm}$ for S-Metolachlor. The mobile phase was composed of acetonitrile (A) and aqueous $\mathrm{H}_{3} \mathrm{PO}_{4}(0.01 \% \mathrm{v} / \mathrm{v}, \mathrm{pH}=2.9)$ (B) at a flow rate of $1 \mathrm{~mL} \cdot \mathrm{min}^{-1}$. Gradient: $0-5 \mathrm{~min}$ : $5 \% \mathrm{~A}$; 
TABLE 1: PCR primers and amplification programs used in this study.

\begin{tabular}{|c|c|c|c|c|c|}
\hline $\begin{array}{l}\text { Target genes and } \\
\text { microbial groups }\end{array}$ & PCR primers & Sequences $\left(5^{\prime}-3^{\prime}\right)$ & Uses & PCR/amplification program & References \\
\hline $\begin{array}{l}\text { Bacterial-16S } \\
\text { rDNA }\end{array}$ & $\begin{array}{l}968 \mathrm{f}^{\mathrm{a}} \\
1401 \mathrm{r}\end{array}$ & $\begin{array}{l}\text { AACGCGAAGAACCTTAC } \\
\text { CGGTGTGTACAAGGCCC }\end{array}$ & DGGE 463 bp & $\begin{array}{l}5 \mathrm{~min} \text {. at } 95^{\circ} \mathrm{C} \text {, followed by } 30 \\
\text { cycles of }\left(1 \mathrm{~min} . \text { at } 95^{\circ} \mathrm{C}, 1 \mathrm{~min} \text {. }\right. \\
\left.\text { at } 58^{\circ} \mathrm{C}, 1 \mathrm{~min} \text {. at } 72^{\circ} \mathrm{C}\right) \text {; a final } \\
\text { extension step for } 7 \mathrm{~min} \text {. at } 72^{\circ} \mathrm{C}\end{array}$ & {$[21]$} \\
\hline $\begin{array}{l}\text { Fungal-5,8S } \\
\text { rDNA/ITS }\end{array}$ & $\begin{array}{l}\text { ITS5 }^{\mathrm{a}} \\
\text { ITS2 }\end{array}$ & $\begin{array}{l}\text { GGAAGTAAAAGTCGTAACAAGG } \\
\text { GCTGCGTTCTTCATCGATGC }\end{array}$ & DGGE $280-600$ bp & $\begin{array}{l}15 \mathrm{~min} \text {. at } 95^{\circ} \mathrm{C} \text {, followed by } 35 \\
\text { cycles of }\left(30 \mathrm{sec} \text {. at } 95^{\circ} \mathrm{C}, 45 \mathrm{sec} \text {. }\right. \\
\left.\text { at } 55^{\circ} \mathrm{C}, 30 \mathrm{sec} \text { at } 72^{\circ} \mathrm{C}\right) \text {; a final } \\
\text { extension step for } 7 \text { min. at } 72^{\circ} \mathrm{C}\end{array}$ & {$[22]$} \\
\hline
\end{tabular}

a For DGGE, a GC clamp (5'-CGC CCG CCG CGC GCG GCG GGC GGG GCG GGG GCA CGG GGG G-3') was attached to 5' end.

5-30 min: 5-70\% A (linear); 30-32 min 70-95\% A; 3233 min: 95-5\% A: 33-36 min: 5\% A.

2.3. Soil Chemical Analysis. Physicochemical characteristics of Limagne soil have already been described in a previous study [9] and checked in this study for any evolutions since the last analyses.

Evolutions of carbohydrates and proteins in soil samples were followed, according to Dubois et al. [12] and Lowry et al. [13], respectively, to estimate the availability of the principal organic compounds which ensure microbial development. Results were read spectrophotometrically on a SFM 25 (Kontron Instruments).

Measurements of ammonium $\left(\mathrm{NH}_{4}{ }^{+}\right)$and nitrate $\left(\mathrm{NO}_{3}{ }^{-}\right)$concentrations were performed within hours following the sampling. For $\mathrm{NH}_{4}{ }^{+}, 2 \mathrm{~g}$ of soil were mixed with $10 \mathrm{~mL}$ of $1 \mathrm{M} \mathrm{KCl}$ and stirred for $1 \mathrm{~h}$ at $250 \mathrm{rpm}$ at room temperature. For $\mathrm{NO}_{3}{ }^{-}, 10 \mathrm{~g}$ of soil were mixed with $50 \mathrm{~mL}$ of deionized water at $40^{\circ} \mathrm{C}$ and stirred for $1 \mathrm{~h}$ at $250 \mathrm{rpm}$ at room temperature. After centrifugation at $4000 \times \mathrm{g}$ during $10 \mathrm{~min}$, supernatants were filtered on a cellulose filter (Whatman 42). $\mathrm{NH}_{4}{ }^{+}$measurements were performed spectrophotometrically on a SFM 25 (Kontron Instruments), directly after filtration, following the Berthelot reaction method [14]. $\mathrm{NO}_{3}{ }^{-}$measurements were performed by ionic chromatography [15]. Samples were run in a Waters $501 \mathrm{HPLC}$ pump (Millipore) at $0.5 \mathrm{~mL} \cdot \mathrm{min}^{-1}$ and conductivity was followed by a Waters 431 detecting device (Millipore). Data was recorded and analysed by TotalChrom Navigator software (PerkinElmer).

2.4. Estimated Soil Microbial Activity and Biomasses. The estimated activity of soil microbial communities was quantified using the substrate-induced respiration (SIR) method. SIR was measured according to Crouzet et al. [9] with $6 \mathrm{mg}$ glucose $\mathrm{g}^{-1}$ soil as performed by Lin and Brookes [16], using a gas chromatograph (Agilent $3000 \mu \mathrm{GC}$, Agilent Technology). SIR results were not converted into biomass values [17] and used as a proxy of the activity level of the heterotrophic active microbial communities.

The total soil microbial biomass was quantified using the fumigation/extraction method described by Vance et al. [18] with slight modifications. Briefly, $10 \mathrm{~g}$ of fresh soil was fumigated in a bell jar vacuum system containing $250 \mathrm{~mL}$ of $\mathrm{CHCl}_{3}$ stabilized with $0.6 \% \mathrm{EtOH}$ at $37^{\circ} \mathrm{C}$ during $24 \mathrm{~h}$. The total carbon (TC) extraction from fumigated and nonfumigated soil samples was performed by adding $40 \mathrm{~mL}$ of $30 \mathrm{mM} \mathrm{K}_{2} \mathrm{SO}_{4}$ and stirring for $40 \mathrm{~min}$ at $250 \mathrm{rpm}$ at room temperature. After centrifugation at $4000 \times \mathrm{g}$ during $10 \mathrm{~min}$, supernatants were filtered on $1.2 \mu \mathrm{m}$ glass microfiber filters (GF/C Whatman). Analyses of TC and inorganic carbon (IC) were performed on a total organic carbon analyzer TOC-5050A (Shimadzu). Each sample was run a minimum of 6 times to get correct values $(P$ value $<0.05)$. Indirect microbial biomass was obtained by using Lin and Brookes general formula: $\mathrm{Bc}=2,22 \times \mathrm{Ec}$ (with $\mathrm{Bc}$, the microbial C. and Ec the $\mathrm{K}_{2} \mathrm{SO}_{4}$-extracted C. in fumigated soil less the $\mathrm{K}_{2} \mathrm{SO}_{4}$-extracted C. in nonfumigated soil) [16].

The photosynthetic microbial biomass was quantified by photosynthetic pigment extraction and measurement (chlorophyll $a$, active chlorophyll $a$, and carotenoids). Pigments were extracted within hours following the sampling, according to Tsujimura et al. [19]. The concentrations of pigments were measured spectrophotometrically from absorbance readings $(480,630,645,663$, and $750 \mathrm{~nm})$ on a CE 2021-2000 series (CECIL Instruments) using the equation described by SCOR-UNESCO Working Group 17 [20].

\subsection{Soil Microbial Structures}

2.5.1. Bacterial Genetic Structure by PCR-DGGE. Bacterial community structure from each microcosm was investigated on genomic DNA extracted and purified from $1 \mathrm{~g}$ of soil using the Ultra Clean Soil DNA isolation kit extraction (MoBio Laboratories) according to the manufacturer's instructions for maximum yields. The quality of DNA extractions was checked on NanoDrop 1000 (Thermo Fisher Scientific). The amplification was run with the primers $968 \mathrm{f}-$ GC and 1401r (Table 1) targeting the V6-V8 regions of bacterial 16S rDNA [21]. The PCR reaction $(50 \mu \mathrm{L})$ contained 1 $\times$ PCR buffer (Bioline), $2.5 \mathrm{mM} \mathrm{MgCl}_{2}$ (Bioline), $200 \mu \mathrm{M}$ of each dNTP (Promega), $0.3 \mu \mathrm{M}$ of each primer, $500 \mathrm{ng} \cdot \mu \mathrm{L}^{-1}$ of bovine serum albumin (BSA, Sigma), 1.5 units of BIOTAQ 
DNA polymerase (Bioline), and $40 \mathrm{ng}$ of soil DNA extract. The samples were amplified in MJ Research thermocycler (PTC-200). PCR products were checked by $0.8 \%(\mathrm{wt} / \mathrm{v})$ agarose gel electrophoresis, stained with ethidium bromide, and quantified with the DNA quantitation Kit (Sigma) using a Kontron spectrofluorometer (Kontron Instruments) at wavelength of $360 \mathrm{~nm}$ (excitation) and $460 \mathrm{~nm}$ (emission). $500 \mathrm{ng}$ of each bacterial PCR product was loaded into 7.5\% polyacrylamide $(\mathrm{w} / \mathrm{v})$ denaturing gels with linear gradients of $50-60 \%$ (100\% denaturant contains $7 \mathrm{M}$ urea and $40 \%$ formamide) and run in $1 \mathrm{X}$ TAE buffer at a temperature of $60^{\circ} \mathrm{C}$ at $80 \mathrm{~V}$ for $21 \mathrm{~h}$ on a TTGEK-2401-220 (CBS Scientific).

2.5.2. Fungal Genetic Structure by PCR DGGE. Fungal community structure was investigated on genomic DNA extracted and purified from a pool of $7.5 \mathrm{~g}$ of soil from the five randomly chosen microcosms for each treatment with PowerMax Soil DNA isolation kit extraction (MoBio Laboratories) according to the manufacturer's instructions for maximum yields. Quality of DNA extractions was checked on NanoDrop 1000 (Thermo Fisher Scientific). The amplification was run with the primers ITS5-GC and ITS2 (Table 1) targeting the ITS and 5.8S rDNA region [22]. The PCR reaction $(50 \mu \mathrm{L})$ contained $1 \times$ PCR buffer (Qiagen), $2.5 \mathrm{mM} \mathrm{MgCl}_{2}$ (Qiagen), $200 \mu \mathrm{M}$ of each dNTP (Promega), $0,3 \mu \mathrm{M}$ of each primer, $500 \mathrm{ng} \cdot \mu \mathrm{L}^{-1}$ of bovine serum albumin (BSA, Sigma), 1.25 units of HotStart Taq DNA polymerase (Qiagen), and $40 \mathrm{ng}$ of soil DNA extract. The samples were amplified in UnoCycler thermocycler (VWR). PCR products were checked as for bacteria. $500 \mathrm{ng}$ of each fungal PCR product was loaded into $7.5 \%$ polyacrylamide $(\mathrm{w} / \mathrm{v})$ denaturing gels with linear gradients of $25-50 \%(100 \%$ denaturant contains $7 \mathrm{M}$ urea and $40 \%$ formamide) and run in $1 \mathrm{X}$ TAE buffer at a temperature of $59^{\circ} \mathrm{C}$ at $70 \mathrm{~V}$ for $16 \mathrm{~h}$ on the same apparatus as for the bacterial PCR products.

After electrophoresis, the DGGE gels were stained in $1 \mathrm{X}$ TAE buffer containing 1/20000 dilution of Gel Star (Lonza, Rockland, ME-USA) and digitized using a BioSpectrumAC Imaging System (UVP).

2.6. Statistical Analyses. All soil microbial measurements were calculated on the basis of oven-dried soil weight and expressed as the mean values $( \pm \mathrm{SEM})$ of five replicates per treatment and per date, except for bacterial DGGE results, where only three replicates were analysed, and for fungal DGGE results. Statistical procedures were carried out using PAST software [23]. Normality distribution and homogeneity of variances were checked for all data. One-way ANOVA was used to test treatment effects on the microbial activities and biomasses, for a given date after herbicide application. Differences between individual means were then compared using Tukey's honest significant difference (HSD) post hoc test. Significance was set at $P \leq 0.05$. Gel analyses were performed using Gel ComparII software (Applied Maths, Kortrijk, Belgium). According to Fromin et al. [24], total band intensity for each lane was normalized among lanes and each DNA band was considered in the analysis if its relative intensity accounted for more than $0.5 \%$ of

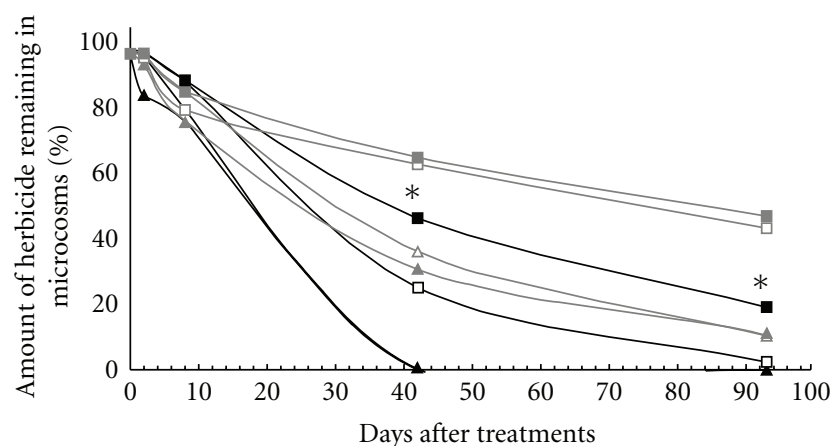

FIGURE 1: Dissipation of Mesotrione (in black) and S-metolachlor (in grey) (in percentage compared to the initial input) applied at $1 \times \mathrm{FR}$ (triangle) and $10 \times \mathrm{FR}$ (square), alone (empty figure) or in "cocktail" (full figure) in the Limagne soil microcosms, during the 93 days of the experiment. Significant differences between dissipation of molecules applied alone and in "cocktail" (labelled by $*$ for $0.01<P \leq 0.05$ ) were observed using one-way ANOVA analyses.

total lane intensity. Data obtained was compared to control results for each sampling date, using the Student's $t$-test for two samples. Based on band position and band relative intensity analysis, the diversity of the microbial communities was analysed by the richness $(R)$ estimated as the number of bands, the Shannon-Weaver index $(\mathrm{H})$ according to the following equation: $H^{\prime}=-\sum \mathrm{Pi}(\ln \mathrm{Pi})$ [25], where $\mathrm{Pi}$ is the ratio between specific band intensity and total intensity of all bands in a lane sample.

\section{Results}

3.1. Herbicide Dissipation. Soil herbicide concentrations just after contamination were very similar to the expected values for all treatments (data not shown). Herbicide dissipation was strongly dependent on application rates. At the same field rate, soil dissipation kinetics of S-metolachlor were similar between microcosms containing Dual Gold applied alone or in a "cocktail" (Figure 1), with a $\mathrm{DT}_{50}$ of $\approx 28$ days at $1 \times \mathrm{FR}$ and $\approx 85$ days at $10 \times \mathrm{FR}$. Cumulative losses at day 93 represented around $89 \%$ and $53 \%$ of the initial S-metolachlor input for $1 \times$ FR- and $10 \times$ FR-treated soils, respectively. At day 42 , microcosms containing Callisto showed Mesotrione concentration at $1 \times \mathrm{FR}$ to be under the detection limit of the device used for the analyses, in both application methods. For the Callisto at $10 \times \mathrm{FR}$, Mesotrione concentrations at days 42 and 93 were statistically lower in microcosms where herbicides had been applied alone. Cumulative losses at day 93 represented around $97.5 \%$ and $80 \%$ of the initial Mesotrione $10 \times \mathrm{FR}$ input for single application and "cocktail" treated soils, respectively. The "cocktail" increased the $\mathrm{DT}_{50}$ of Mesotrione $\left(\mathrm{DT}_{50}\right.$ of $\approx 40$ days in "cocktail" against $\approx 28$ days in alone application).

3.2. Effects on Edaphic Parameters. Among the initial physicochemical soil characteristics, organic matter (OM) concentration was at $29.9 \mathrm{~g} \cdot \mathrm{kg}^{-1}$ with a $\mathrm{pH}$ value of 6.5 (supplementary data 1 ). 
$\mathrm{NH}_{4}{ }^{+}$concentrations increased during the first 42 days of experimentation (Figure 2). Two days after the treatment, $\mathrm{NH}_{4}{ }^{+}$concentrations were statistically higher in C10 microcosms, compared to T, M1, and M10. The results evolved at day 8 and 42 , with statistically higher concentrations of $\mathrm{NH}_{4}{ }^{+}$ in DG10, M1, and M10 microcosms, compared to T and C1.

Whatever the treatment or the sampling date, no effect was observed on $\mathrm{NO}_{3}{ }^{-}$(average values ranged from 62.3 to $107.8 \mu \mathrm{g} \cdot \mathrm{g}_{\mathrm{dw}}^{-1}$ ) and proteins concentrations (average values ranged from 0.67 to $1.33 \mathrm{mg} \cdot \mathrm{g}_{\mathrm{dw}}^{-1}$ ) in microcosms (data not shown).

Carbohydrate concentrations stayed quite similar, whatever the treatment and the sampling date (ranging from 2.18 to $2.62 \mathrm{mg} \cdot \mathrm{g}_{\mathrm{dw}}^{-1}$ ), except at day 8 where statistical increases of glucose equivalent in DG10, M1, and M10 microcosms were observed, compared to control microcosms (Figure 3).

3.3. Effects on Microbial Biomasses and Activity. A statistical decrease of microbial carbon was observed between day 2 (values ranged from 385 to $449 \mu \mathrm{g} \cdot \mathrm{g}_{\mathrm{dw}}^{-1}$ ) and day 93 (values ranged from 319 to $384 \mu \mathrm{g} \cdot \mathrm{g}_{\mathrm{dw}}^{-1}$ ) (supplementary data 2). At each sampling date, the total soil microbial carbon value showed no statistical differences between treatments.

The general pattern observed for the SIR experiment was a global increase in $\mathrm{CO}_{2}$ of $0.015 \%$ per hour for all microcosms. No difference was observed between control and treatments, whichever day was considered (data not shown).

The photosynthetic microbial biomass, assessed by measuring photosynthetic pigments, showed no statistical difference between treatments until the 42nd day of experimentation, where total chlorophyll, active chlorophyll $a$, and carotenoid concentrations displayed similar patterns of responses for the different treatments. At day 93 (Figure 4), whereas chlorophyll $a$ concentrations in T and $\mathrm{Cl}$ microcosms were statistically higher than other treatments, carotenoid concentrations in T microcosms were only statistically higher than the DG10 and M10 microcosms. Active chlorophyll $a$ was monitored to give an estimation of active biomass of autotrophic communities and showed statistically less active chlorophyll $a$ in C10, M1, and M10 microcosms compared to T. Moreover, in $\mathrm{C} 1$ microcosms, active chlorophyll $a$ was always higher than other treatments whereas carotenoid was different to DG1, DG10, M1, and M10 microcosms.

3.4. Effects on Microbial Community Structures. The diversity of the results obtained from DGGE gels showed a large band number, with 24 to 53 for bacterial gels and from 34 to 48 for fungal gels. Community structures showed a complex diversity with major bands commonly found in all microcosms and a lot of minor bands. Some communities, therefore, seemed to be stimulated by the presence of herbicides in microcosms with one or both herbicides (supplementary data 3 ).

At day 2, the bacterial diversity results (Table 2) showed that richness in $\mathrm{C} 10$ microcosms was much higher than

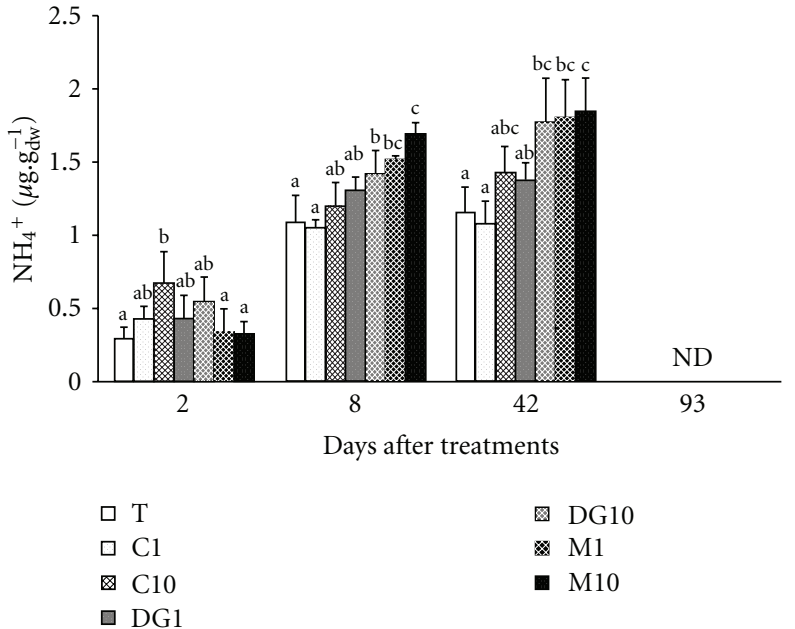

FIGURE 2: Ammonium $\left(\mathrm{NH}_{4}{ }^{+}\right)$content $\left(\mu \mathrm{g} \cdot \mathrm{g}_{\mathrm{dw}}^{-1}\right)$, depending on soil treatments: control $(\mathrm{T})$, Callisto $1 \times \mathrm{FR}(\mathrm{C} 1)$ and $10 \times \mathrm{FR}(\mathrm{C} 10)$, Dual Gold $1 \times$ FR $(\mathrm{DG} 1)$ and $10 \times \mathrm{FR}(\mathrm{DG} 10)$, and Callisto/Dual Gold Mix $1 \times$ FR (M1) and $10 \times$ FR (M10), and sampling dates. No data was obtained for day 93 (ND). Different letters above the bars (mean \pm standard deviation; $n=5$ ) show treatments significantly different for a given sampling date using one-way ANOVA followed by the Tükey post hoc test $(P<0.05)$.

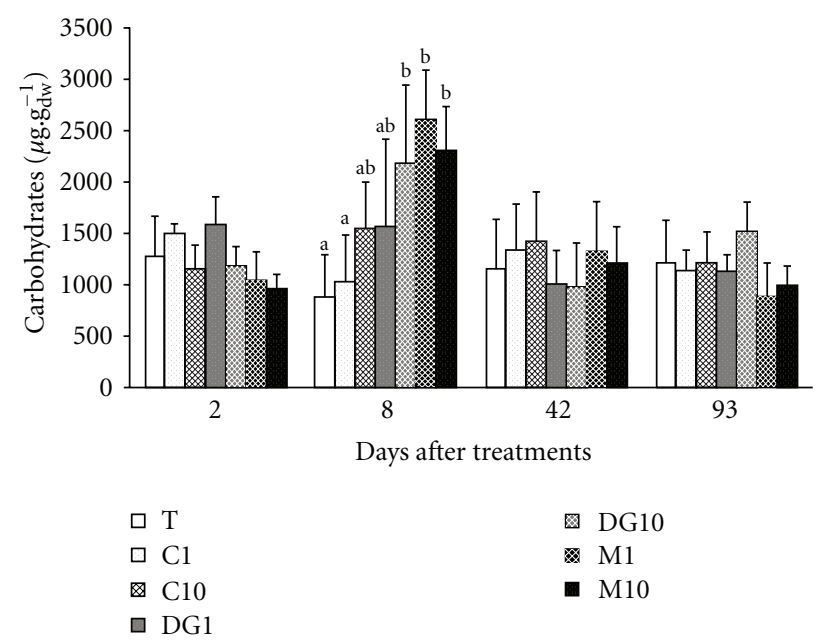

FIGURE 3: Carbohydrate content (glucose equivalent, $\left(\mu \mathrm{g} \cdot \mathrm{g}_{\mathrm{dw}}^{-1}\right)$, depending on soil treatments: control $(\mathrm{T})$, Callisto $1 \times \mathrm{FR}(\mathrm{C} 1)$ and $10 \times \mathrm{FR}(\mathrm{C} 10)$, Dual Gold $1 \times \mathrm{FR}(\mathrm{DG} 1)$ and $10 \times \mathrm{FR}(\mathrm{DG} 10)$, and Callisto/Dual Gold Mix $1 \times$ FR (M1) and $10 \times$ FR (M10), and sampling dates. Different letters above the bars (mean \pm standard deviation; $n=5$ ) show treatments significantly different for a given sampling date using one-way ANOVA followed by the Tükey post hoc test $(P<0.05)$.

control (T). At the same day, however, the ShannonWeaver index $\left(H^{\prime}\right)$ showed a decrease of overall diversity in $\mathrm{C} 1$ microcosms and an increase in C10, DG10, and M1 microcosms. The only differences observed at days 8 and 42 were a decrease of DG1 band numbers. At day 93, C10 and $\mathrm{M} 1$ microcosms presented poor richness compared to $\mathrm{T}$ microcosms, and in M1 and M10 microcosms the diversity indicator $\left(H^{\prime}\right)$ was statistically lower. 
TABle 2: Richness $(N)$ and the Shannon-Weaver $\left(H^{\prime}\right)$ index, estimated from DGGE fingerprints of bacterial 16S rDNA and fungal rDNA (ITS) genes, respectively. Comparisons were made between control and treatments for a given sampling date. Bacterial results were reported as means $( \pm$ SEM $)(n=3)$.

\begin{tabular}{|c|c|c|c|c|c|c|c|c|}
\hline \multirow{3}{*}{ Soil treatments } & \multicolumn{2}{|c|}{ Day 2} & \multicolumn{2}{|c|}{ Day 8} & \multicolumn{2}{|c|}{ Day 42} & \multicolumn{2}{|c|}{ Day 93} \\
\hline & $N$ & $H^{\prime}$ & $N$ & $H^{\prime}$ & $N$ & $H^{\prime}$ & $N$ & $H^{\prime}$ \\
\hline & \multicolumn{8}{|c|}{ Estimated by analysis of bacterial DGGE fingerprints } \\
\hline $\mathrm{T}$ & $32,7 \pm 1,8$ & $2,99 \pm 0,05$ & $38,7 \pm 1,8$ & $3,24 \pm 0,12$ & $47,7 \pm 3,1$ & $3,58 \pm 0,10$ & $38,3 \pm 1,6$ & $3,41 \pm 0,04$ \\
\hline $\mathrm{C} 1$ & $31,7 \pm 1,8$ & $2,77 \pm 0,05^{*}$ & $35,3 \pm 2,2$ & $3,21 \pm 0,05$ & $47,3 \pm 4,4$ & $3,60 \pm 0,13$ & $34,0 \pm 2,0$ & $3,31 \pm 0,07$ \\
\hline $\mathrm{C} 10$ & $43,0 \pm 2,0^{* *}$ & $3,30 \pm 0,09^{*}$ & $33,3 \pm 2,4$ & $3,17 \pm 0,06$ & $42,0 \pm 4,0$ & $3,55 \pm 0,07$ & $34,0 \pm 1,3^{*}$ & $3,33 \pm 0,04$ \\
\hline DG1 & $34,0 \pm 1,3$ & $3,02 \pm 0,03$ & $33,0 \pm 1,3^{*}$ & $3,11 \pm 0,07$ & $38,0 \pm 2,0^{*}$ & $3,37 \pm 0,05$ & $35,0 \pm 1,3$ & $3,35 \pm 0,04$ \\
\hline DG10 & $36,3 \pm 0,4$ & $3,24 \pm 0,03^{* *}$ & $30,3 \pm 4,2$ & $2,93 \pm 0,17$ & $41,3 \pm 1,8$ & $3,42 \pm 0,05$ & $32,3 \pm 3,6$ & $3,14 \pm 0,14$ \\
\hline M1 & $33,3 \pm 0,9$ & $3,19 \pm 0,03^{*}$ & $33,0 \pm 3,7$ & $3,02 \pm 0,01$ & $42,7 \pm 4,9$ & $3,47 \pm 0,11$ & $35,0 \pm 0,0^{*}$ & $3,28 \pm 0,02 *$ \\
\hline M10 & $31,0 \pm 0,0$ & $3,11 \pm 0,07$ & $32,7 \pm 3,6$ & $2,96 \pm 0,19$ & $48,0 \pm 3,3$ & $3,51 \pm 0,09$ & $35,0 \pm 1,3$ & $3,31 \pm 0,02 *$ \\
\hline
\end{tabular}

\begin{tabular}{lllcccccc} 
& \multicolumn{7}{c}{ Estimated by analys of fungal DGGE fingerprints } \\
T & 48 & 3,55 & 40 & 3,29 & 47 & 3,54 & 35 & 3,27 \\
C1 & 47 & 3,49 & 42 & 3,41 & 39 & 3,39 & 38 & 3,46 \\
C10 & 47 & 3,42 & 39 & 3,33 & 38 & 3,34 & 40 & 3,51 \\
DG1 & 47 & 3,45 & 35 & 3,16 & 42 & 3,45 & 36 \\
DG10 & 45 & 3,34 & 45 & 3,33 & 39 & 3,4 & 37 & 3,39 \\
M1 & 48 & 3,56 & 43 & 3,25 & 40 & 3,38 & 34 & 3,41 \\
M10 & 48 & 3,48 & 38 & 3,06 & 41 & 3,44 & 37 \\
\hline
\end{tabular}

Means followed by * are significantly different $(P \leq 0.05)$, and $* *$ highly significantly different $(P \leq 0.01)$ from control (T) for a given sampling date using the Student's $t$-test for two samples.

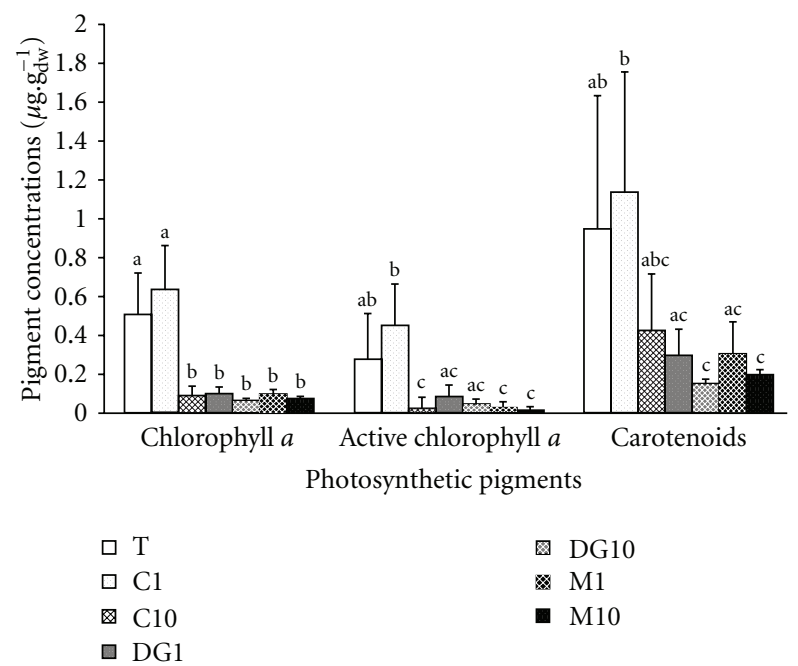

Figure 4: Pigment concentrations $\left(\mu \mathrm{g} \cdot \mathrm{g}_{\mathrm{dw}}^{-1}\right)$ at day 93, depending on soil treatments: control $(\mathrm{T})$, Callisto $1 \times \mathrm{FR}(\mathrm{C} 1)$ and $10 \times \mathrm{FR}(\mathrm{C} 10)$, Dual Gold $1 \times \mathrm{FR}(\mathrm{DG} 1)$ and $10 \times \mathrm{FR}(\mathrm{DG} 10)$, and Callisto/Dual Gold Mix $1 \times$ FR (M1) and $10 \times$ FR (M10). Different letters above the bars (mean \pm standard deviation; $n=5$ ) show treatments significantly different for a given sampling date using one-way ANOVA followed by the Tükey post hoc test $(P<0.05)$.

A global decrease of richness in fungal communities was observed between day 2 and day 93 ( $P \leq 0.05)$, but there was no change in the $H^{\prime}$ index.

\section{Discussion}

This study focused on analysing the unknown effects on soil microbial diversity and activities of a "cocktail" of herbicides used for maize crops. As far as we know, it is the first study using the Mesotrione $+S$-metolachlor mixture, despite the fact that these molecules are recommended in many pesticide applications to control undesirable vegetation. The effects recorded may have resulted from the combined impact of herbicides, adjuvants, and degradation products.

4.1. Herbicides Fate in Soil. Despite the fact that nonwater extractable residues have not been quantified in this study, the known Koc values of both herbicides led us to consider that there was little possibility of such formations occurring [26, 27] (Agritox, http://www.dive.afssa.fr/agritox/ index.php/). Furthermore, as Mesotrione and S-metolachlor have little sensitivity to photodegradation [28] (Agritox, http://www.dive.afssa.fr/agritox/index.php/), we can conclude that biodegradation could explain their decreasing concentration in soil microcosms (Figure 1). Moreover, the $35 \%$ of maximum WHC represented optimal conditions for microbial growth and allowed a good distribution of herbicides in the soil for biodegradation. Mesotrione decrease was faster than S-metolachlor decrease, which complies with Crouzet et al. [9] $\mathrm{DT}_{50}$ results for Mesotrione, and Ma et al. [29] for S-metolachlor. Mesotrione dissipation was longer when associated with S-metolachlor and its adjuvants at $10 \times$ FR. This observation has already been noted by other authors who have demonstrated that the combined use of herbicides in a "cocktail" $[4,5]$, or the association of herbicides and fungicides [30], could increase their persistence in soil. We can subsequently conclude that the S-metolachlor and/or additive compounds (adjuvants) contained in Dual Gold, which were certainly different from those in Callisto, could act on Mesotrione availability by modifying solubility or sorption parameters [31] and/or impact microorganisms 
potentially capable of Mesotrione degradation, resulting in herbicide persistence in the soil. Additional compounds, however, may be responsible for the effects observed in the "cocktail" microcosms: for example, alcohol ethoxylates (AEOs) and alkylamine ethoxylates (ANEOs) pesticide adjuvants have demonstrated their toxicity on small eukaryotes and bacteria [32] even at low concentrations.

4.2. How do Microbial Communities Respond to Herbicide Applications? Herbicides were originally designed for their effects on plants. They are, however, potentially capable of directly or indirectly altering soil microbial communities which include organisms sensitive to the parent molecule and/or degradation products $[1,33]$. In this study, the pollution pressure, in terms of active ingredients, was found to remain until the end of the experiment for all the treated microcosms, except for C1 (Figure 1).

When applied alone and at the recommended field rate, Callisto (C1) showed no statistical differences compared to the control microcosms, except for a small decrease in bacterial diversity assessed using the Shannon-Weaver index (Table 2). These results are close to those observed by Crouzet et al. [9], who concluded that this herbicide when applied at the recommended field rate, had a nonsignificant impact on soil microbial communities. The soil used in our microcosms was different to that used by Crouzet et al. in terms of percentage of sand and silt and $\mathrm{pH}$ values (supplementary data 1$)$. The increase of the porosity $(37 \%$ of sand against $23 \%$ in 2007) could have modified the retention properties of molecules in the soil by increasing the Mesotrione access to microorganisms, thereby ensuring faster degradation and short-term impacts. The results obtained for Dual Gold treatment (DG1) with the same application dose, showed a higher impact on microbial communities, with a decrease of bacterial richness at days 8 and 42, and a decrease of chlorophyll $a$ concentrations at day 93. We can conclude, therefore, that these herbicides, when applied at the recommended field rate, acted differently on microbial communities and produced nondesired effects. Dual Gold impacted microbial communities longer than Callisto, however, at the end of the experimentation, $\mathrm{C} 1$ and DG1 (except for chlorophyll $a$ concentration) were similar to T microcosms.

According to the SIR results, microbial communities were equally active in control and treated microcosms throughout the whole experiment. The SIR results showed the same pattern as the one observed in the Zabaloy et al. study [34] for 2,4-D and metsulfuron-methyl at 10 $\times$ FR, but differed from others $[9,35]$, where pesticide supplementation increased the respiration activity. Currently, no general pattern of microbial responses can be inferred regarding pesticide identity, doses applied, exposure time, soil type, or other environmental factors [36-38]. Moreover, the total microbial biomass and protein concentrations showed no statistical differences between treatments during the experimentation at any given sampling date.

The absence of effects in SIR, microbial carbon, and protein measurements could be explained by the hypoth- esis submitted by Wardle and Parkinson [39], whereby a microbial community under the effects of herbicides was presumably in a considerable state of flux, with susceptible microbes being killed and others, thereby, having a readily available source of carbon.

With reference to the results concerning carbohydrates (Figure 3), herbicides in "cocktail" microcosms (M1 and M10) at day 8 could produce such an effect by killing microorganisms, such as bacteria and fungi, which would result in a decrease of bacterial richness and diversity (Table 2) and an increase in sugar concentrations. Moreover, increases of labile substrates and organic matter could be used by the resistant population (supplementary data 3) and influence the nitrogen cycle, which would explain the increase in ammonium found in "cocktail" microcosms at days 8 and 42. Similar results were observed with C10 treatments as early as day 2 , where a short-term effect on bacterial communities had been noticed, with increases in some populations (Table 2) and ammonium concentrations (Figure 2). This could not be considered, however, as a general effect of pesticides, as underlined by Lo in his review [1], where pesticides produced both increases and decreases in nitrogen activities.

Another explanation for this increase in ammonium concentration could be an inhibition of the nitrification process resulting in a reduced use of ammonium by microbial communities. Notwithstanding the above, herbicide treatments did not modify the amounts of nitrates. This leads us to consider the possibility of small effects made by ammonium shifts, not recorded by our analyses, given the high values of nitrate measured, equivalent to $10^{2}$ to $10^{3}$ superior than ammonium concentrations. Additional data would be necessary, however, to link this increase in ammonium to a specific community. Although it was not one of the objectives of this study, it would be prudent to use specific primers to target those microbial communities involved in the nitrogen cycle to provide data to confirm this hypothesis [40, 41].

At the end of the experimentation, bacterial structure results (Table 2) showed a decrease in microbial diversity for "cocktail" microcosms. This is not linked to microbial abundance results and might be masked by the global effects on microbial communities [39]. It underlined, however, a long-term synergetic effect of the application of "cocktails."

Another impact is clearly recorded (Figure 4) on the same day, being the colonization of the surface of "cocktails" and $\mathrm{C} 10$ microcosms by phototrophic communities. The impact of Callisto on photosynthetic pigments, particularly on the HPPD enzyme, in some phototrophic microbial communities, inhibited the colonization of such communities throughout the experimentation period. The "cocktail" affects total and active chlorophyll $a$ in ideal growth conditions [19], primarily because of the duality of the targets covered by the two herbicides for phototrophic communities.

These results underlined the fact that a simple "cocktail" at $1 \times \mathrm{FR}$ can impact the microbial community as much as a single molecule used at $10 \times$ FR. Furthermore, "cocktail" 
results are closer to those obtained for $10 \times$ FR Dual Gold applications (DG10) than to $10 \times$ FR Callisto applications (C10).

\section{Conclusion}

The results obtained in this study clearly showed that when applied alone at the recommended field rate doses, the herbicides Callisto and Dual Gold exert only few consistent minor effects on soil microbial communities. The study confirmed, however, that a "cocktail" of such herbicides applied at $1 \times \mathrm{FR}$, has an effect on microbial communities also confirmed at $10 \times \mathrm{FR}$.

The results of this study show the deleterious effect of even low quantities of herbicide "cocktails" on soil microbial communities and must be used with caution despite the supposedly low dangerousness of these new molecules for the environment. Knowing that pesticide "cocktails" of herbicides, fungicides, insecticides, and many other molecules are the current trend in agricultural practices, it is essential that we investigate more precisely their impact with more sensitive methodologies and approaches, and focus on specific microbial communities which ensure key functional steps in biogeochemical cycles. Functional communities involved in $\mathrm{N}$-cycling provide good microbial ecology models to study the role of size and structure of microbial communities on corresponding process rates and ecosystem functions [40, 42]. Moreover, phototrophic communities could be used as bioindicator of pesticide "cocktails" stresses. Any further studies should not underestimate the number of pesticides which can be applied in combinations or "cocktails," and must focus on specific parameters and specific microbial communities to obtain an overall understanding of their potential impact.

\section{Conflict of Interests}

The authors declare that there is no conflict of interests.

\section{Acknowledgments}

The authors would like to thank D. Tottey, English native translator, for the English review of this paper, B. Debote from Crouël INRA (Institut National de la Recherche Agroalimentaire) for providing soil samples, G. Maillot from LPMM (Laboratoire Photochimie Moléculaire et Macromoléculaire) for technical assistance on carbon measurements, J. Lavedrine from UBP (Université Blaise Pascal) Chemistry Department for technical assistance on nitrate measurements, R. Nouaille from LMGE for technical assistance on the SIR measurements, and S. Fontaine from Crouël INRA for technical assistance on fumigation/extraction experiments.

\section{References}

[1] C. C. Lo, "Effect of pesticides on soil microbial community," Journal of Environmental Science and Health-Part B Pesticides,
Food Contaminants, and Agricultural Wastes, vol. 45, no. 5, pp. 348-359, 2010.

[2] B. C. M. Guimarães, J. B. A. Arends, D. van der Ha, T. van de Wiele, N. Boon, and W. Verstraete, "Microbial services and their management: recent progresses in soil bioremediation technology," Applied Soil Ecology, vol. 46, no. 2, pp. 157-167, 2010.

[3] G. Mitchell, D. W. Bartlett, T. E. M. Fraser et al., "Mesotrione: a new selective herbicide for use in maize," Pest Management Science, vol. 57, no. 2, pp. 120-128, 2001.

[4] K. B. LI, J. T. Cheng, X. F. Wang, Y. Zhou, and W. P. Liu, "Degradation of herbicides atrazine and bentazone applied alone and in combination in soils," Pedosphere, vol. 18, no. 2, pp. 265-272, 2008.

[5] M. Tejada, "Evolution of soil biological properties after addition of glyphosate, diflufenican and glyphosate+diflufenican herbicides," Chemosphere, vol. 76, no. 3, pp. 365-373, 2009.

[6] G. Muyzer, E. C. De Waal, and A. G. Uitterlinden, "Profiling of complex microbial populations by denaturing gradient gel electrophoresis analysis of polymerase chain reactionamplified genes coding for $16 \mathrm{~S}$ rRNA," Applied and Environmental Microbiology, vol. 59, no. 3, pp. 695-700, 1993.

[7] IFEN, “Les pesticides dans l'eau, données 2003 et 2004," 2006.

[8] C. D. S. Tomlin, "The e-pesticide manual," in Council TBCP, 12th edition, 2002.

[9] O. Crouzet, I. Batisson, P. Besse-Hoggan et al., "Response of soil microbial communities to the herbicide mesotrione: a dose-effect microcosm approach," Soil Biology and Biochemistry, vol. 42, no. 2, pp. 193-202, 2010.

[10] J. L. Bonnet, F. Bonnemoy, M. Dusser, and J. Bohatier, “Toxicity assessment of the herbicides sulcotrione and mesotrione toward two reference environmental microorganisms: tetrahymena pyriformis and Vibrio fischeri," Archives of Environmental Contamination and Toxicology, vol. 55, no. 4, pp. 576-583, 2008.

[11] L. A. Burrows and C. A. Edwards, "The use of integrated soil microcosms to predict effects of pesticides on soil ecosystems," European Journal of Soil Biology, vol. 38, no. 3-4, pp. 245-249, 2002.

[12] M. Dubois, K. Gilles, J. K. Hamilton, P. A. Rebers, and F. Smith, "A colorimetric method for the determination of sugars," Nature, vol. 168, no. 4265, p. 167, 1951.

[13] O. H. Lowry, N. J. Rosebrough, A. L. Farr, and R. J. Randall, "Protein measurement with the Folin phenol reagent," The Journal of biological chemistry, vol. 193, no. 1, pp. 265-275, 1951.

[14] E. D. Rhine, G. K. Sims, R. L. Mulvaney, and E. J. Pratt, "Improving the Berthelot reaction for determining ammonium in soil extracts and water," Soil Science Society of America Journal, vol. 62, no. 2, pp. 473-480, 1998.

[15] M. A. Murcia, A. Vera, R. Ortiz, and F. García-Carmona, "Measurement of ion levels of spinach grown in different fertilizer regimes using ion chromatography," Food Chemistry, vol. 52, no. 2, pp. 161-166, 1995.

[16] Q. Lin and P. C. Brookes, "Comparison of methods to measure microbial biomass in unamended, ryegrass-amended and fumigated soils," Soil Biology and Biochemistry, vol. 28, no. 7, pp. 933-939, 1996.

[17] N. C. Banning and D. V. Murphy, "Effect of heat-induced disturbance on microbial biomass and activity in forest soil and the relationship between disturbance effects and microbial community structure," Applied Soil Ecology, vol. 40, no. 1, pp. 109-119, 2008. 
[18] E. D. Vance, P. C. Brookes, and D. S. Jenkinson, "An extraction method for measuring soil microbial biomass C," Soil Biology and Biochemistry, vol. 19, no. 6, pp. 703-707, 1987.

[19] S. Tsujimura, H. Nakahara, and N. Ishida, "Estimation of soil algal biomass in salinized irrigation land: a comparison of culture dilution and chlorophyll a extraction methods," Journal of Applied Phycology, vol. 12, no. 1, pp. 1-8, 2000.

[20] SCOR-UNESCO, Determination of Photosynthetic Pigments in Sea Waters, Center UP, New York, NY, USA, 1966.

[21] H. Heuer, M. Krsek, P. Baker, K. Smalla, and E. M. H. Wellington, "Analysis of actinomycete communities by specific amplification of genes encoding 16S rRNA and gelelectrophoretic separation in denaturing gradients," Applied and Environmental Microbiology, vol. 63, no. 8, pp. 3233-3241, 1997.

[22] T. J. White, T. D. Bruns, S. Lee, and J. Taylor, Amplification and Direct Sequencing of Fungal Ribosomal RNA Genes for Phylogenetics, Academic Press, New York, NY, USA, 1990.

[23] O. Hammer, D. A. T. Harper, and P. D. Ryan, PAST: Palaeontological Statistics Software Package for Education and Data Analyses, P. Electronica, 2001.

[24] N. Fromin, J. Hamelin, S. Tarnawski et al., "Statistical analysis of denaturing gel electrophoresis (DGE) fingerprinting patterns," Environmental Microbiology, vol. 4, no. 11, pp. 634-643, 2002.

[25] C. E. Shannon and W. Weaver, The Mathematical Theory of Communication, University of Illinois Press, Champaign, Ill, USA, 1963.

[26] J. S. Dyson, S. Beulke, C. D. Brown, and M. C. G. Lane, "Adsorption and degradation of the weak acid mesotrione in soil and environmental fate implications," Journal of Environmental Quality, vol. 31, no. 2, pp. 613-618, 2002.

[27] S. M. Novak, J. M. Portal, and M. Schiavon, "Effects of soil type upon metolachlor losses in subsurface drainage," Chemosphere, vol. 42, no. 3, pp. 235-244, 2001.

[28] S. Durand, P. Amato, M. Sancelme, A. M. Delort, B. Combourieu, and P. Besse-Hoggan, "First isolation and characterization of a bacterial strain that biotransforms the herbicide mesotrione," Letters in Applied Microbiology, vol. 43, no. 2, pp. 222-228, 2006.

[29] Y. MA, W. P. LIU, and Y. Z. WEN, "Enantioselective degradation of Rac-metolachlor and S-metolachlor in soil," Pedosphere, vol. 16, no. 4, pp. 489-494, 2006.

[30] P. M. White, T. L. Potter, and A. K. Culbreath, "Fungicide dissipation and impact on metolachlor aerobic soil degradation and soil microbial dynamics," Science of the Total Environment, vol. 408, no. 6, pp. 1393-1402, 2010.

[31] C. Beigel, M. P. Charnay, and E. Barriuso, "Degradation of formulated and unformulated triticonazole fungicide in soil: effect of application rate," Soil Biology and Biochemistry, vol. 31, no. 4, pp. 525-534, 1999.

[32] K. A. Krogh, B. Halling-Sørensen, B. B. Mogensen, and K. V. Vejrup, "Environmental properties and effects of nonionic surfactant adjuvants in pesticides: a review," Chemosphere, vol. 50, no. 7, pp. 871-901, 2003.

[33] K. Johnsen, C. S. Jacobsen, V. Torsvik, and J. Sørensen, "Pesticide effects on bacterial diversity in agricultural soils-a review," Biology and Fertility of Soils, vol. 33, no. 6, pp. 443453, 2001.

[34] M. C. Zabaloy, J. L. Garland, and M. A. Gómez, "An integrated approach to evaluate the impacts of the herbicides glyphosate, 2,4-D and metsulfuron-methyl on soil microbial communities in the Pampas region, Argentina," Applied Soil Ecology, vol. 40, no. 1, pp. 1-12, 2008.
[35] S. K. Chen, C. A. Edwards, and S. Subler, "A microcosm approach for evaluating the effects of the fungicides benomyl and captan on soil ecological processes and plant growth," Applied Soil Ecology, vol. 18, no. 1, pp. 69-82, 2001.

[36] Q. Lin and P. C. Brookes, "Comparison of substrate induced respiration, selective inhibition and biovolume measurements of microbial biomass and its community structure in unamended, ryegrass-amended, fumigated and pesticide-treated soils," Soil Biology and Biochemistry, vol. 31, no. 14, pp. 19992014, 1999.

[37] R. Pal, K. Chakrabarti, A. Chakraborty, and A. Chowdhury, "Degradation and effects of pesticides on soil microbiological parameters-a review," International Journal of Agricultural Research, vol. 1, pp. 240-258, 2006.

[38] D. A. Wardle and D. Parkinson, "Relative importance of the effect of 2,4-D, glyphosate, and environmental variables on the soil microbial biomass," Plant and Soil, vol. 134, no. 2, pp. 209219, 1991.

[39] D. A. Wardle and D. Parkinson, "Effects of three herbicides on soil microbial biomass and activity," Plant and Soil, vol. 122, no. 1, pp. 21-28, 1990.

[40] D. Chèneby, A. Brauman, B. Rabary, and L. Philippot, "Differential responses of nitrate reducer community size, structure, and activity to tillage systems," Applied and Environmental Microbiology, vol. 75, no. 10, pp. 3180-3186, 2009.

[41] S. Henry, D. Bru, B. Stres, S. Hallet, and L. Philippot, "Quantitative detection of the nosZ gene, encoding nitrous oxide reductase, and comparison of the abundances of $16 \mathrm{~S}$ rRNA, narG, nirK, and nosZ genes in soils," Applied and Environmental Microbiology, vol. 72, no. 8, pp. 5181-5189, 2006.

[42] G. A. Kowalchuk and J. R. Stephen, "Ammonia-oxidizing bacteria: a model for molecular microbial ecology," Annual Review of Microbiology, vol. 55, pp. 485-529, 2001. 

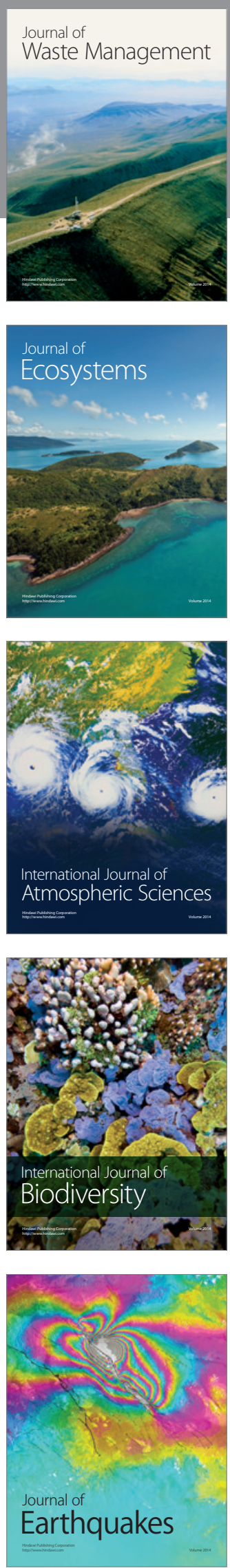
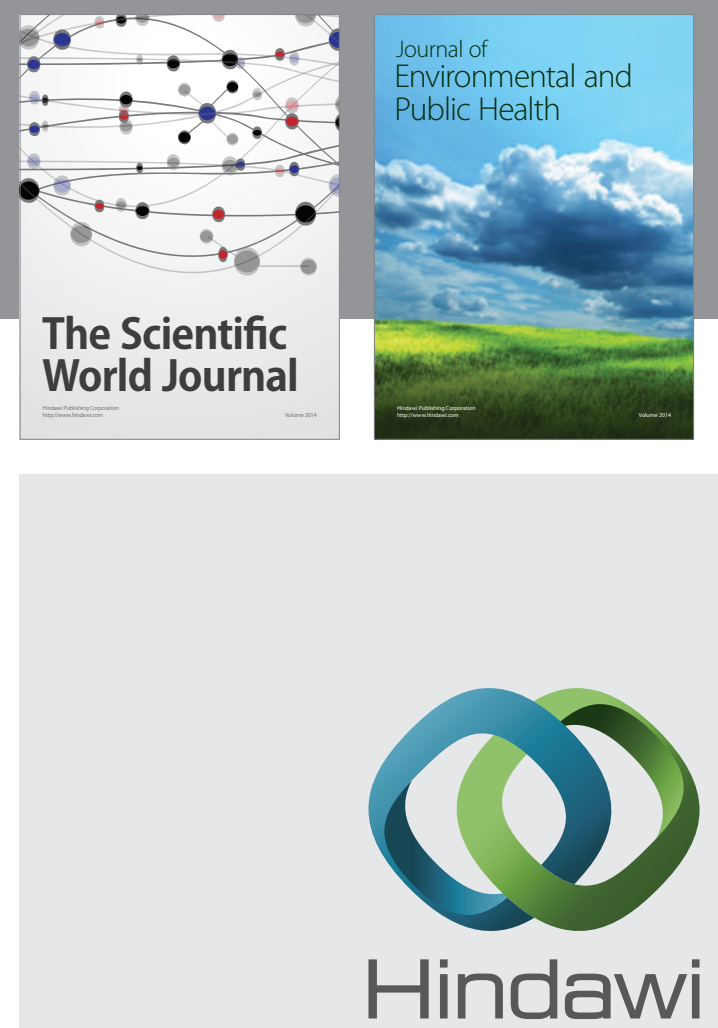

Submit your manuscripts at

http://www.hindawi.com
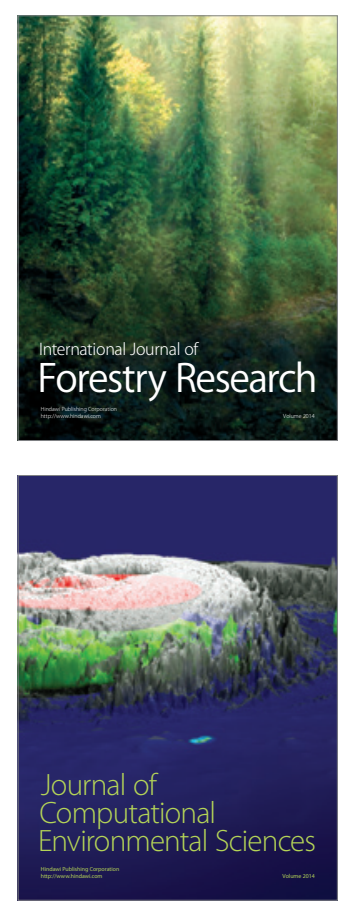
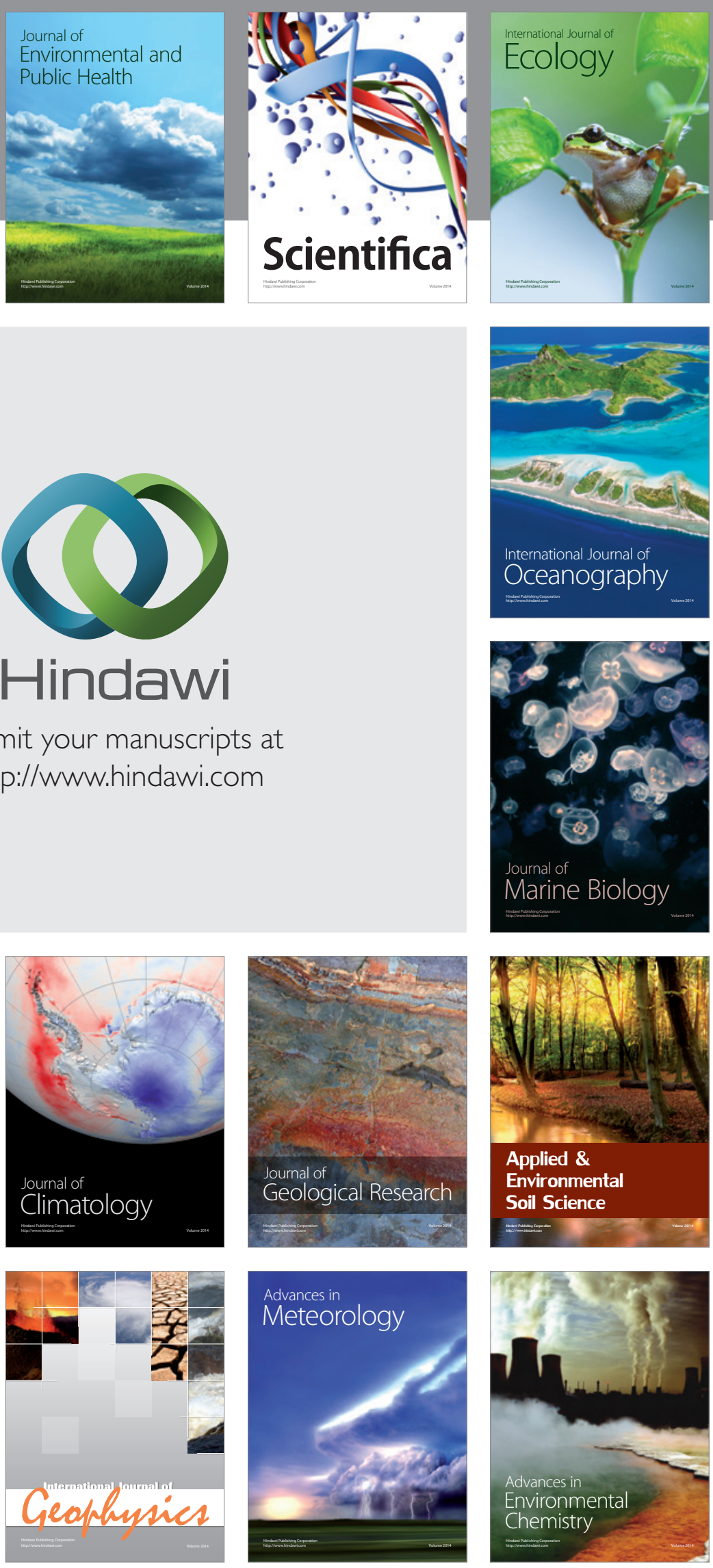